\title{
https://doi.org/10.46813/2020-130-083 \\ RELAXATION OF EDGE DISLOCATIONS IN METALS UNDER THE ACTION OF EXTERNAL STRESSES
}

\author{
B.V. Borts ${ }^{1}$, S.F. Skoromnaya ${ }^{1}$, V.I. Tkachenko ${ }^{1,2}$ \\ ${ }^{1}$ National Science Center “Kharkov Institute of Physics and Technology”, Kharkiv, Ukraine; \\ ${ }^{2}$ V.N. Karazin Kharkiv National University, Kharkiv, Ukraine \\ E-mail: borts@kipt.kharkov.ua
}

The study of the relaxation of edge dislocations (ED) in metals under the action of alternating external stresses of various natures is of great practical interest for estimating of workability of structural elements and functional materials of nuclear power and thermonuclear fusion power plants. In the model of the inhomogeneous dissipative sine - Gordon equation for different values of the amplitude and frequency of the external harmonic force, as well as for different values of dislocation friction, the nonlinear dynamics of ED with fixed ends is studied numerically. The formation of breather-type solitons on the ED is shown, the maximum amplitude of which decreases with increasing dislocation friction. The resonance dependence of the kinetic energy of ED oscillations on the frequency of the external field is described. It has a maximum value for the resonant frequency and decreases with increasing numerically found resonance frequencies.

PACS: 05.45.Yv, 61.72.Bb, 61.72.Lk, 62.20.F-, 83.10.Rs

\section{INTRODUCTION}

It is known that in metals and alloys, as well as in their welded joints, which have experienced large plastic, thermal, fatigue and radiation effects, there are decrease in ductility and a shift in strength properties to the region of brittle fracture during brittle-plastic transitions [1, 2].

Obviously, such a change in the properties of metals and alloys is a consequence of the formation of such structures as:

- accumulation of high-density crystal lattice defects;

- clusters;

- interphase boundaries and boundaries of fragments that form a complex distribution of internal stress fields.

Under external influences, two main directions for the evolution of such structures can be distinguished. The first scenario is accompanied by the appearance of microcracks and their subsequent development, which leads to the destruction of the material. Considerable attention in the literature is paid to the study of the corresponding mechanisms (see, for example, [3]).

The second direction is the use of relaxation mechanisms based on the activation of diffusion and dislocation processes to increase the plasticity of the material.

From a scientific point of view, it is of great interest to study relaxation processes in metals, which are in the region of microplasticity when exposed to low-intensity alternating stresses of various nature. Such stresses, for example, are applied to structural elements and functional materials of power plants of nuclear power or thermonuclear fusion.

In [4], the results of calculating the modes of generation of multisoliton perturbations in the approximation of a modified string dislocation model are described. The possibility of the appearance of double kinks is shown when external alternating stresses with amplitudes below the Peierls stress are applied. The mechanism of movement of double kinks makes it possible to describe the microplastic flow in dislocation clusters, at the boundaries of fragments, or near other sources of peak internal stresses. This mechanism can lead to a redistribution of dislocations and point defects, as well as relaxation of internal stress fields in a metal. It is shown experimentally that the effect of striction stresses excited by an alternating magnetic field with small amplitudes (0.5 ...3.0 MPa) causes softening and plasticization of deformed and irradiated ferritic and austenitic steels.

The obtained practical results show the validity of the scenario of relaxation of internal peak stresses in heterogeneous structures in the region of microplasticity under the action of double kinks on dislocations under conditions when a low-amplitude alternating stress acts in the absence of sources of other dislocations.

The most realistic way to trace the dynamics of an edge dislocation under the influence of an external periodic stress, taking into account internal friction, is possible using the example of the inhomogeneous dissipative sine-Gordon (SG) equation [5, 6], which we will call the generalized string model.

In a particular case, in the absence of external stresses and dissipation, the SG equation has analytical solutions in the form of solitons [7]. It is shown here that solitons are characterized by rather high stability of their shape. In [8], the spatial dispersion parameter was used to describe the free motion of a dislocation in the field of the Peierls potential within the framework of the generalized string model. This approach made it possible to obtain an analytical expression for the transverse displacement of a dislocation, and with its help to demonstrate the possibility of reducing the effect of radiation embrittlement of metals.

A simple theory was proposed in $[5,9]$ to describe the action of small perturbations on solitons (kinks and antikinks), which are described by the SG equation. This theory is based on the expansion of a small change in the soliton profile in terms of the complete system of eigenfunctions of the differential operator.

One of the possible applications of the inhomogeneous dissipative SG equation is the description of the dynamics of edge dislocations in a real crystal. With this approach, the edge dislocation is 
represented as an elastic string with rigidly fixed ends. This string vibrates relative to its initial position in the medium with absorption $[10,11]$.

If we proceed from the stability of the shape of solitons, then there is an assumption that its motion along an edge dislocation with a small perturbation of the shape due to the small effect of external factors [12] can lead to multiple overcoming of the Peierls barrier by the dislocation, and, ultimately, to its emergence on metal grain border.

In [13], the nonlinear dynamics of an edge dislocation was investigated on the basis of the classical model of Granato-Lucke, which is described by the inhomogeneous dissipative SG equation. The influence of the equilibrium internal crawl force $(\mathrm{CF})$ on the dynamics of an edge dislocation is investigated. In the equilibrium state, the $\mathrm{CF}$ acts in the direction perpendicular to the Burgers vector and is balanced by the force of internal friction. When the segment of the edge dislocation is displaced from the equilibrium position, the $\mathrm{CF}$ creates an effective acceleration, in the field of which the motion of the string can be considered as a wave on the surface of the liquid. Based on this interpretation, an additional convective term was obtained in the SG equation, which takes into account the effect of the CF.

For an unbounded string, it was established that the propagation velocity of SG solitons (kinks) is determined by the ratio of the $\mathrm{CF}$ to the friction force. The existence of solitons propagating with the speed of sound, the shape of which depends on the direction of propagation, is shown.

For a dislocation string fixed at the ends, its nonlinear dynamics is investigated at various values of the internal friction force, $\mathrm{CF}$ and the frequency of change of the external harmonic force. Numerical calculations have shown that under the action of an external harmonic force, the amplitude of the deflection of a dislocation string from the equilibrium position can be comparable to or exceeds the lattice period. Under such conditions, it is possible to displace a dislocation along the extraplane over distances that significantly exceed the lattice period. The resonant character of the increasing of the average string kinetic energy as a function of the frequency of the external harmonic force and the magnitude of $\mathrm{CF}$ is shown.

The aim of this work is to study the resonant increasing of the average dislocation string kinetic energy as a function of the frequency of the external harmonic force and the magnitude of internal friction in the absence of a CF.

\section{BASIC EQUATION}

According to [13], the SG equation, taking into account the external periodic force, dislocation friction, but in the absence of the $\mathrm{CF}$ has the form:

$$
m \frac{\partial^{2} w}{\partial t^{2}}-K_{0} \frac{\partial^{2} w}{\partial x^{2}}+b \sigma_{P} \sin \left(\frac{2 \pi w}{a}\right)=b F(t)-\delta^{\prime} \frac{\partial w}{\partial t},
$$

with zero boundary conditions at the ends of the string $w(0, t)=w(L, t)=0$, where $m=\left(\rho b^{2} / 4 \pi\right) \ln (L / b)-$ effecttive mass per unit length of a dislocation; $\rho$-density of matter; $b$ - Burgers vector; $\delta^{\prime}=\left(10^{-5} \ldots 10^{-2}\right) \mathrm{kg} /(\mathrm{m} \cdot \mathrm{s})$
$[12,14,15]$ - dislocation friction coefficient; $K_{0}=G m / \rho-$ dislocation linear tension coefficient; $G$ -crystal shear modulus; $\sigma_{P}=\left(10^{-4} \ldots 10^{-2}\right) G$ - Peierls characteristic stress; $L=\left(10 \ldots 10^{4}\right) b-$ dislocation characteristic length; $F(t)=F\left(t+T_{0}\right)$ - external periodic force; $T_{0}$ - external force time period.

For dimensionless displacement $y=2 \pi w / a$, and in dimensionless variables $t=\tau t_{0}, x=\xi x_{0}$, equation (1) and the boundary conditions to it take the form:

$$
\begin{aligned}
& \frac{\partial^{2} y}{\partial \tau^{2}}-\frac{\partial^{2} y}{\partial \xi^{2}}+\sin (y)=\Phi(\tau)-\delta \frac{\partial y}{\partial \tau}, \\
& y(0, \tau)=y\left(L / x_{0}, \tau\right)=0,
\end{aligned}
$$

where $t_{0}^{2}=a m /\left(2 \pi b \sigma_{P}\right) ; \quad x_{0}=s_{0} t_{0} ; \quad s_{0}^{2}=K_{0} / m$; $\delta=\delta^{\prime} t_{0} / m ; \quad \beta=g^{*} x_{0} / s_{0}^{2} ; \quad \Phi(\tau)=F(\tau) / \sigma_{P} ; \quad a-$ crystal lattice constant.

Nonlinear vibrations of a dislocation string in the absence of an external periodic force $(|\Phi(\tau)|=0))$ with fixed ends were analyzed numerically in [13].

It was shown here that oscillations of a string with fixed ends at long times are described by a multisoliton solution. At the initial moment of time, kink and antikink solitons moving towards them are excited. Then the amplitude of the string deflection goes into the region of negative values, apparently due to the presence of one more soliton solution - a breather [16 18]. Further dynamics of the string is irregular, but limited in amplitude. It is noted that an increase in the number of solitons is due to multiple scattering of the arose at the initial time soliton-like perturbation at the ends of the string.

In contrast to the problem described above, let us consider the effect of an external force on the character of oscillations of a dislocation string in the presence of dissipation. Let us set the external force in a model form:

$$
\Phi(\tau)=\Phi(0) \cdot \cos (\Omega \tau),
$$

where $\Phi(0)$ - external periodic force amplitude.

Since there are no analytical solutions to equation (2), we will use the numerical simulation method to solve the problem.

In the numerical calculations, we used the same hybrid approximation scheme as before [13]. The frequency of the external force was set equal to: $\Omega=0.5 ; 1.0 ; 1.5 ; 2.0$. The dislocation friction coefficient was determined by the numbers: $\delta=0.1 ; 0.5 ; 1.0$.

The results of numerical simulation of equation (2) with zero boundary conditions are shown in Figs. 1,a-h. These figures show a surface that is swept away by a dislocation string in the process of its deviation from its initial position. As an example, a dimensionless string length of 10 units was chosen, and the observation time for the string dynamics was set equal to 40 .

In the figures the ED is a segment of a straight line at the initial moment of time. 


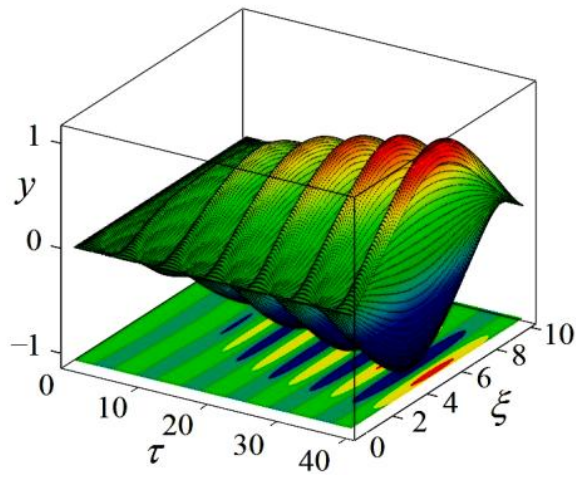

a: $\Phi(0)=0.1 ; \Omega=1.0 ; \delta=0.1$

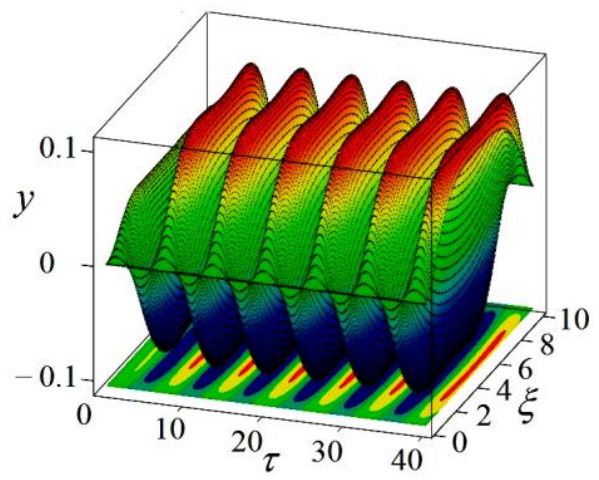

c: $\Phi(0)=0.1 ; \Omega=1.0 ; \delta=1.0$

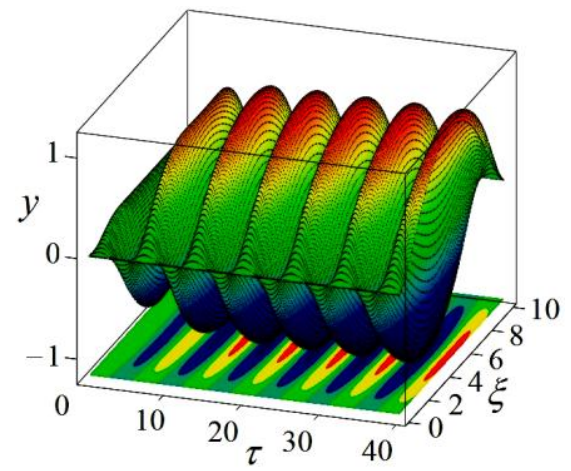

e: $\Phi(0)=0.5 ; \Omega=1.0 ; \delta=0.5$

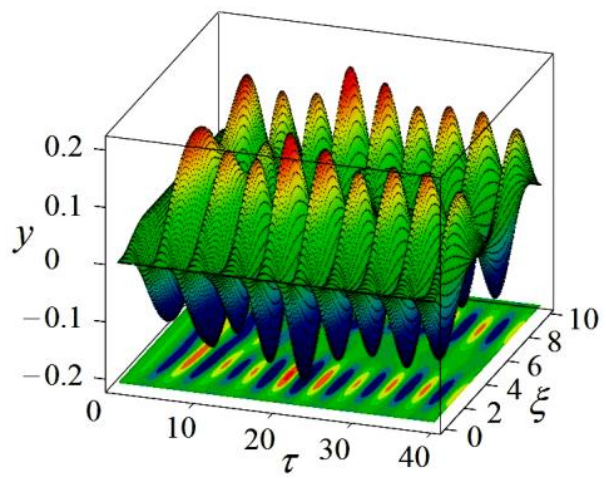

$\mathrm{g}: \Phi(0)=0.1 ; \Omega=1.5 ; \delta=0.1$

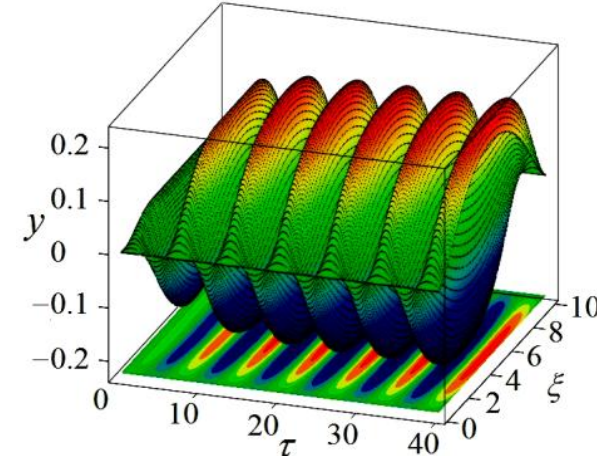

b: $\Phi(0)=0.1 ; \Omega=1.0 ; \delta=0.5$

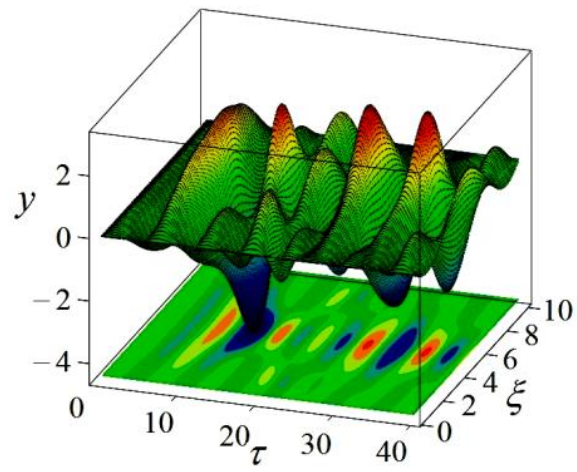

$\mathrm{d}: \Phi(0)=0.5 ; \Omega=1.0 ; \delta=0.1$

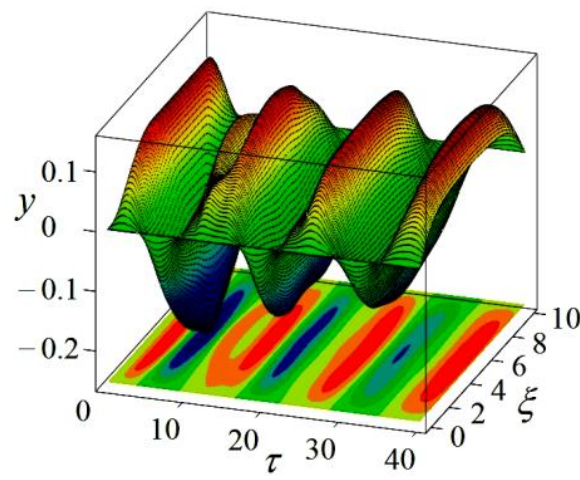

f: $\Phi(0)=0.1 ; \Omega=0.5 ; \delta=0.1$

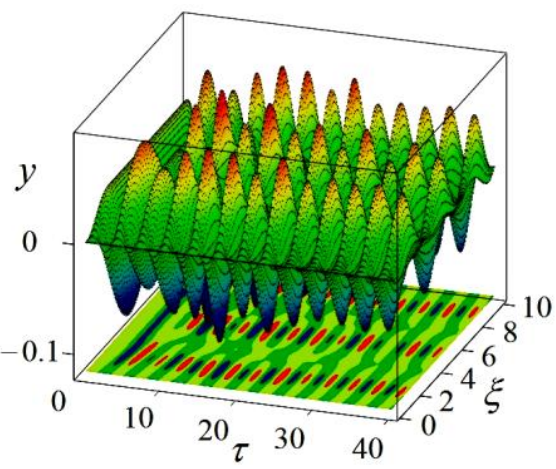

h: $\Phi(0)=0.1 ; \Omega=2.0 ; \delta=0.1$

Fig. 1. Displacement of ED for different amplitudes and frequencies of an external periodic field at different levels of dislocation friction

The initial position of the ED can be seen in Fig. 1, a, the shape of the swept surface, but also by the level and in the remaining figures it is hidden by the surface swept by the string. With the passage of time, the string deviates from the initial position with the formation of a breather-type soliton, which can be judged not only by

lines shown in (see Fig. 1), below the swept surfaces.

It follows from the figures that with an increase in dislocation friction, the maximum amplitude of string deflections decreases (see Figs. 1,a,c,d,e). 
For small values of the initial amplitude of the external periodic force and for small dislocation friction, the dependence of the amplitude of the edge dislocation deviation on the time and frequency of oscillations is shown in Figs. 1,f,a,g,h. It follows from these figures that with an increase in the frequency of the external force, the amplitude of displacement of the dislocation string is maximum at $\Omega=1,0$. This indicates the resonant nature of the vibration excitation. At frequencies below and above the resonance, the displacement amplitude of the ED is less than the resonant one.

For frequencies below the resonant one, there is a transition from one standing breather to another (see Fig. 1,f).

One standing breather is excited at the resonant frequency.

For frequencies above the resonance, a breather is also observed. However, it has different characteristics from the resonant breather. This breather moves between the stoppers of the ED, has a half-width less than the resonance breather (approximately by a factor

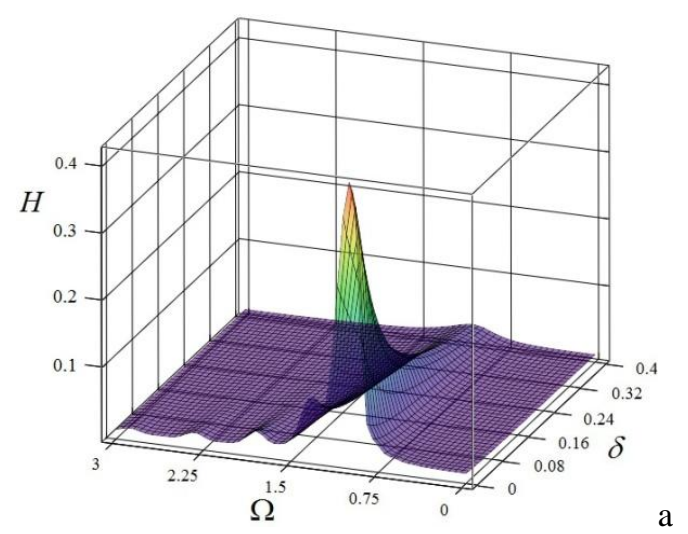

a

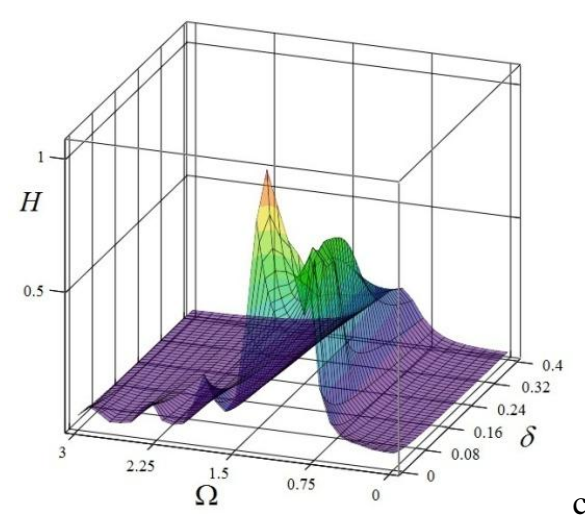

$\Omega^{-1}$ times) and by the same amount of time a shorter period of oscillations. It follows from the results of numerical calculations that the amplitude of the deviation of the ED from the initial position can reach such a value at which the ED can overcome the Peierls barrier and go into the neighboring lattice period.

Thus, by setting the amplitude of the external periodic force, the ED in the direction of the grain boundary can be displaced in the slip plane.

\section{KINETIC ENERGY OF VIBRATIONS OF ED IN THE FIELD OF EXTERNAL PERIODIC FORCE IN THE PRESENCE OF DISLOCATION FRICTION}

The estimation of the dependence of the kinetic energy of a ED on the external field and dislocation friction was carried out using a functional that determines the average kinetic energy of a string with a length $L$ over a certain period of time $T[12,13]$ :

$$
W=\frac{m}{2} \frac{1}{L T} \int_{0}^{L} \int_{0}^{T}\left(\frac{\partial w}{\partial t}\right)^{2} d t d x .
$$
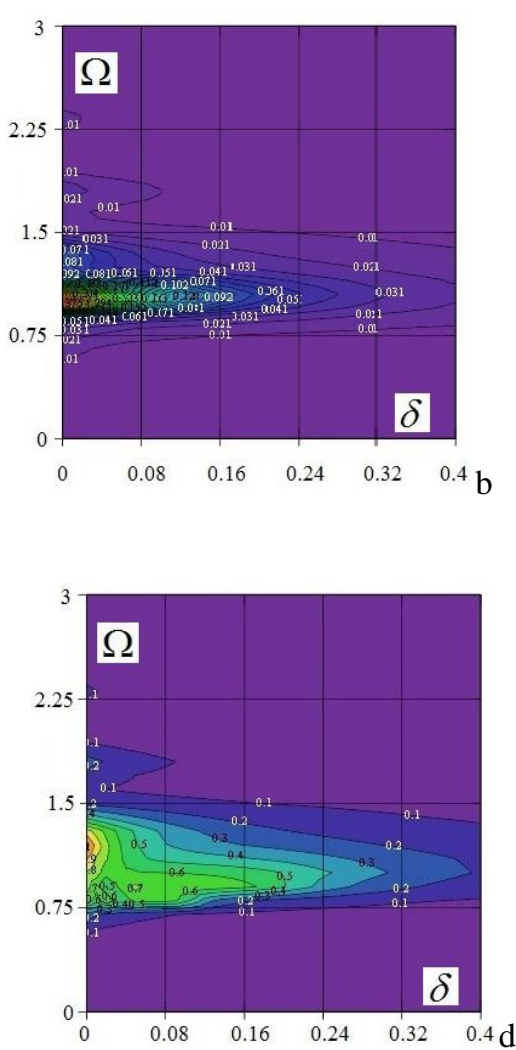

Fig. 2. Dependence of the average kinetic energy of the ED on the dimensionless frequency of the external force $\Omega$ and dislocation friction $\delta$ at:

$|\Phi(0)|=0,1, a$ - general view, $b$-level lines; $|\Phi(0)|=0,3, c-$ general view; $d$-level lines

In units of characteristic kinetic energy, the functional takes the form:

$$
H \equiv \frac{W}{Q}=\frac{1}{\xi_{*} \tau_{*}} \int_{0}^{\tau_{*}} \int_{0}^{\xi_{*}}\left(\frac{\partial y}{\partial \tau}\right)^{2} d \tau d \xi,
$$

where $Q=0.5 m a^{2}(2 \pi)^{-2} t_{0}^{-2}$. Numerical calculations of functional (4) were carried out for the amplitude of the external force $\Phi(0)=0.3$, values of dimensionless frequency $0.0 \leq \Omega \leq 3.0$ and dislocation friction $0.0 \leq \delta \leq 0.4$. The calculation results are shown in Fig. 2.

From Fig. 2 it follows that at low levels of dissipation, the external field acts in a resonant manner on the ED: the kinetic energy of the ED acquires a maximum value for the resonant frequency $\Omega=1.0$. 
Calculations show that an increase in the initial amplitude of the external periodic force $\Phi(0)$ leads to an increase in the kinetic energy of the string $H$.

The graphs of the dependence of the average kinetic energy of the string on the frequency of the external force and on the magnitude of dislocation friction show the existence of at least 5 resonance frequencies of a noticeable magnitude. At small amplitudes of the external force, when $\Phi(0)=0.01 ; 0.1$ and at $\delta<<1$, the resonant frequencies $\Omega_{i}(i=1 ; 2 ; \ldots ; 5 i=1 ; 2 ; \ldots ; 5)$ are arranged in the following order: $\Omega_{1}=(1.054 ; 1.023)$, $\Omega_{2}=(1.33 ; 1.36), \Omega_{3}=(1.81 ; 1.84), \Omega_{4}=(2.33 ; 2.36)$, $\Omega_{5}=(2.88 ; 2.91)$, where the order of the resonance frequencies in parentheses corresponds to the order of the amplitudes of the external force $\Phi(0)$.

With an increase in the initial amplitude of the periodic external field, when $\Phi(0)=0.2 ; 0.3$, the first resonance $\Omega_{1}=1$ at the initial moment of time is divided into two resonant frequencies, which are located to the right and left of the first resonance $\Omega_{1 l}>\Omega_{1}>\Omega_{1 r}$. The right resonance frequency $\Omega_{1 r}$ shifts to the region of lower frequencies, the stronger, the greater the initial field amplitude. The left resonance frequency $\Omega_{1 l}$, on the contrary, shifts to the region of higher frequencies, the weaker, the greater the initial field amplitude. In this case, the frequencies $\Omega_{1 l}$ and $\Omega_{2}$ approach each other, and the average kinetic energy of the ED at this frequency increases in comparison with the case of a small initial amplitude of the periodic external field. Over time, resonances $\Omega_{1 l}$ and $\Omega_{1 r}$ converge to $\Omega_{1}$.

Numerical calculations show that the vibration amplitude of a ED can be comparable with the lattice period. Under such conditions, it can move in the slip plane of the dislocation in the direction of the action of the external periodic force into the potential well of the neighboring Peierls barrier It's corresponds to some degree relaxation of external stress in the crystal.

\section{CONCLUSIONS}

In this work, within the framework of the model of the inhomogeneous dissipative SG equation, the nonlinear dynamics of ED with fixed ends for various values of the amplitude and frequency of the external harmonic force is investigated by numerical methods, taking into account dislocation friction of various magnitudes.

It is shown that with time the ED deviates from the initial position with the formation of a breather-type soliton. In this case, with an increase in dislocation friction, the maximum amplitude of ED decreases.

Numerical calculations for small values of the initial amplitude of the external periodic force $\Phi(0)=0.1$ and for dislocation friction $\delta=0.1$ have shown that the dependence of the amplitude of the deflection of the ED on the oscillation frequency of the external periodic force has a resonant character, i.e. the displacement amplitude of the ED is maximum at $\Omega=1.0$. One standing breather is excited at the resonant frequency. At frequencies below and above the resonance, the displacement amplitude of the ED is less than the resonant one.

For the frequency of the external field, below the resonant frequency $\Omega<1.0$, a transition from one standing breather to another over time is observed.

For frequencies higher than the resonant, a breather is also excited, but with characteristics different from the resonant breather. It moves between the stoppers of the ED, has a smaller half-width (approximately by a factor of $\Omega^{-1}$ times) and by the same number of times a smaller oscillation period than a resonance breather.

An analysis of the set of the average kinetic energy of vibrations of the ED in the field of an external periodic force in the presence of a small dislocation friction showed that the kinetic energy of the string acquires a maximum value for the frequency. It was noted that an increase in the initial amplitude of the external periodic force at the resonant frequency leads to an increase in the kinetic energy of the string.

An analysis of the acquisition of the average kinetic energy of $\mathrm{CD}$ vibrations in the field of an external periodic force in the presence of a small dislocation friction showed that the kinetic energy of the ED has a maximum value for the frequency $\Omega=\Omega_{1}=1.0$. It was noted that an increase in the initial amplitude of the external periodic force at the resonant frequency leads to an increase in the kinetic energy of the ED.

For the dependence of the average kinetic energy of the ED on the frequency of the external force and on the dislocation friction, the existence of resonance frequencies was found. By the example of calculating five resonant frequencies of the average kinetic energy of a ED, their change depending on the initial amplitude of the periodic external force is described. It is shown that with an increase in the initial amplitude of the periodic external field, when $\Phi(0)=0.2 ; 0.3$, the first resonant frequency $\Omega_{1}$ is splits into two resonant frequencies, which are located to the right and left of it: $\Omega_{1 l}>\Omega_{1}>\Omega_{1 r}$.

The right resonance frequency $\Omega_{1 r}$ shifts to the region of lower frequencies, the stronger, the greater the initial field amplitude. The left resonance frequency $\Omega_{1 l}$, on the contrary, shifts to the region of higher frequencies, the weaker, the greater the initial field amplitude. In this case, the frequencies $\Omega_{1 l}$ and $\Omega_{2}$ approach each other, and the average kinetic energy of the ED at this frequency increases in comparison with the case of a small initial amplitude of the periodic external field.

With the passage of time, the resonances $\Omega_{1 l}$ and $\Omega_{1 r}$ converge to $\Omega_{1}$, and the value of the average kinetic energy of the ED tends to zero.

From the results of numerical calculations, it follows that the amplitude of the deviation of the ED from the initial position can reach such a value at which the one can overcome the Peierls barrier and go into the adjacent lattice period. It's corresponds to some degree relaxation of external stress in the crystal. 


\section{REFERENCES}

1. A.P. Gulyayev. Metallovedeniye. Uchebnik dlya vuzov. M.: «Metallurgiya», 1986, 544 p. (in Russian).

2. V.M. Aleksandrov. Materialovedeniye i tekhnologiya konstruktsionnykh materialov. Uchebnoye posobiye. Arkhangel'sk: Severnyy (Arkticheskiy) federal'nyy universitet, 2015, 327 p. (in Russian).

3. D.U. Kallister, D.D. Retvich. Materialovedeniye. Ot tekhnologii k primeneniyu. Metally, keramika, polimery. Sankt-Peterburg: Nauchnyye osnovyi tekhnologii, 2011, 896 p. (in Russian).

4. Y.M. Neklyudov, V.Y. Sokolenko, V.Y. Tkachenko. O relaksatsyy defektnykh struktur y vnutrennykh napryazhenyy v metallakh // Fizychni yavyshcha $v$ tverdykh tilakh. Mat. 9-i Mizhnar. konf. 1-4 hrudnya 2009, Kharkiv: KHNU, 2009, s. 93 (in Ukrainian).

5. M.B. Fogel, S.E. Trullinger, A.R. Bishop, J.A. Krumhansl. Dynamics of sine - Gordon solitons in the presence of perturbations // Phys. Rev. B. 1977, v. 15 , № 3, p. 1578-1592.

6. G. Reinisch, J. C. Fernandez. Specific sine - Gordon soliton dynamics in the presence of external driving forces // Phys. Rev. B. 1981, v. 24, № 2, p. 835- 844.

7. R. Dodd, D. Eylbek, D. Gibbon, X. Morris. Solitony $i$ nelineynyye volnovyye uravneniya. M.: «Mir», 1988, 694 p. (in Russian).

8. P.M. Neklyudov, V.N. Voyevodin, L.S. Ozhigov, A.G. Rudenko, A.A. Parkhomenko, V.V. Krasil'nikov, S.Ye. Savotchenko. Temperaturnyye zavisimosti mekhanicheskikh svoystv i radiatsionnoye uprochneniye materialov II. Metally s OTSK i GPU reshetkami // Izvestiya Tul'skogo Gos. Un-ta. Seriya «Fizika». 2004, v. 4, p. 93-100 (in Russian).

9. M.B. Fogel, S.E. Trullinger, A.R. Bishop, J.A. Krumhansl // Phys. Rev. Lett. 1976, v. 36, № 24, p. 1411-1414 (in Russian).
10. A. Granato, K. Lyukke. Dislokatsionnaya teoriya pogloshcheniya // Ul'trazvukovyye metody issledovaniya dislokatsiy. M., 1963, s. 27-57 (in Russian).

11. O.A. Troitskiy, V.G. Shteynberg. Radiatsionnaya fizika prochnosti metallicheskikh kristallov. M.: «Atomizdat», 1969, 79 p. (in Russian).

12. V.V. Krasil'nikov, S.Ye. Savotchenko, I.V. Udovenko. Vnutrenneye treniye $\mathrm{V}$ solitonnoy modeli dislokatsionnoy dinamiki v kristallakh // Izvestiya Tul'skogo Gos. Un-ta. Seriya «Fizika», 2005, № 5, p. 71-79 (in Russian).

13. B.V. Borts, I.M. Neklyudov, S.F. Skoromnaya, V.I. Tkachenko. Nelineynaya dinamika krayevykh dislokatsiy vo vneshnikh polyakh i ikh vklad v formirovaniye granitsy soyedineniya $\mathrm{v}$ tverdoy faze raznorodnykh metallov pri prokatke v vakuume // Fizika i khimiya obrabotki materialov. 2012, № 3, p. 61-69 (in Russian).

14. D. Niblett, Dzh. Uilks. Vnutrenneye treniye v metallakh, svyazannoye s dislokatsiyami // UFN. 1963, № 80 , v. 1, p. 125-187.

15. V.I. Al'shits, V.L. Indenbom Dinamicheskoye tormozheniye dislokatsiy // UFN. 1975, № 111, v. 1, p. 3-39.

16. D. Maklaflin. Fizicheskoye opisaniye spektral'nogo preobrazovaniya // Nelineynyye elektromagnitnyye volny. M.: «Mir», 1983, 312 p. (in Russian).

17. R. Parment'ye. Flyuksony v raspredelennykh dzhozefsonovskikh kontaktakh // Solitony v deystvii. M.: «Mir», 1981, s. 185-209 (in Russian).

18. M. Steiner. Dynamics of One-Dimensional Magnets. Neutron Scattering Studies // Physics in One Dimension. Berlin Heidelberg, 1981, p. 140-152.

Article received 10.09.2020

\section{РЕЛАКСАЦИЯ КРАЕВЫХ ДИСЛОКАЦИЙ В МЕТАЛЛАХ ПОД ДЕЙСТВИЕМ ВНЕШНИХ НАПРЯЖЕНИЙ}

\section{Б.В. Бори, С.Ф. Скоромная, В.И. Ткаченко}

Изучение релаксации краевых дислокаций (КД) в металлах под действием переменных внешних напряжений различной природы представляет большой практический интерес для оценки работоспособности элементов конструкции и функциональных материалов ядерных и термоядерных электростанций. В модели неоднородного диссипативного уравнения синуса - Гордона, для различных значений амплитуды и частоты внешней гармонической силы, а также для разных значений дислокационного трения численно исследуется нелинейная динамика КД с закрепленными концами. Показано формирование на КД солитонов бризерного типа, максимальная амплитуда которых уменьшается с увеличением трения дислокации. Описана резонансная зависимость кинетической энергии колебаний КД от частоты внешнего поля. Она имеет максимальное значение для резонансной частоты и уменьшается с увеличением численно найденных резонансных частот.

\section{РЕЛАКСАЦІЯ КРАЙОВИХ ДИСЛОКАЦІЙ У МЕТАЛАХ ПІД ДІЕЮ ЗОВНІШНІХ НАПРУГ Б.В. Бори, С.Ф. Скоромна, В.І. Ткаченко}

Вивчення релаксації крайових дислокацій (КД) у металах під дією змінних зовнішніх напруг різної природи представляє великий практичний інтерес для оцінки працездатності елементів конструкції i функціональних матеріалів ядерних і термоядерних електростанцій. У моделі неоднорідного дисипативного рівняння синуса - Гордона для різних значень амплітуди і частоти зовнішньої гармонійної сили, а також для різних значень дислокаційного тертя числовими методами досліджується нелінійна динаміка КД 3 закріпленими кінцями. Показано формування на КД солітонів брізерного типу, максимальна амплітуда яких зменшується зі збільшенням тертя дислокації. Описана резонансна залежність кінетичної енергії коливань КД від частоти зовнішнього поля. Кінетична енергія коливань КД має максимальне значення для резонансної частоти і зменшується зі збільшенням знайдених числовими методами резонансних частот. 